Erratum

\title{
Erratum to: Effect of In-Service Strengthening on the Axial Load Carrying Capacity of Steel Box Columns
}

\author{
Saeed Erfani*, Mohsen Naseri, and Vahid Akrami
}

Civil Engineering Department, Amirkabir University of Technology, Tehran, Iran

(c) KSSC and Springer 2017

Erratum to: International Journal of Steel Structures 17(1): 231-244 (2017) DOI 10.1007/s13296-015-0178-x

Zeinoddini-Meimand, V., M. Ghassemieh and J. Kiani "Finite Element Analysis of Flush End Plate Moment Connections under Cyclic Loading."

The above reference should be revised as below;

Zeinoddini-Meimand, V., Ghassemieh, M. and Kiani, J. (2014). "Finite element analysis of flush end plate moment connections under cyclic loading." International Journal of Civil, Architectural Science and Engineering, 8(1), pp. 96104. 